\title{
Legers ansvar etter bortfall av autorisasjon
}

\author{
Jeg er blant de mange som valgte å la være å søke om forlenget autorisasjon etter fylte 75 år. Jeg fortsatte \\ å betale ansvarsforsikringen. En autorisert lege har omfattende plikter som er nedfelt i lovverket. Etter \\ opphør av autorisasjon gjenstår den personlige moralske plikten, men hvordan er det med det juridiske \\ ansvaret? Og har ansvarsforsikringen noen verdi for den forsikrede legen som ikke har autorisasjon?
}

Publisert først på nett 7.3. 2012

$\AA ̊$ oppgi sin identitet som lege, selv om det gjelder «bare» juridiske plikter og rettigheter, er tungt for de fleste. Mange oppfatter nok dette som den endelige eksklusjon fra fellesskapet (1). Dette var trolig noe av årsaken til at jeg $i$ to år uten autorisasjon fortsatt betalte min ansvarsforsikring. Først i januar 2012 hadde jeg så stor avstand til å være «har-vært-lege» at jeg forsto at fortsatt betaling sannsynligvis var bortkastet.

Jeg sendte derfor 25.1. 2012 en e-post til Legeforeningen: «Dere vil se at jeg fylte 75 år uten å søke om forlenget lisens for vel 2 år siden. Jeg har likevel fått tilsendt giroblankett for betaling for ansvarsforsikring, og har betalt den til og med 2011, fordi jeg har antatt at dette er i samsvar med foreningens anbefaling. Ved dagens mottak av krav for 2012, ber jeg om at foreningen avklarer om fortsatt ansvarsforsikring $i$ det hele kan ha noen verdi uten opprettholdt lisens. I så fall vil jeg selvsagt fortsette å betale.»

Legeforeningen svarte dagen etter: «Legeforeningen får ingen oversikt over de leger som ikke søker om forlengelse av sin lisens. Vi avslutter ingen forsikring uten å få beskjed om dette fra medlemmet selv. Siden du ikke innehar lisensen lenger så avslutter vi din ansvarsforsikring.»

Foranstående er gjengitt som informasjon til dem som er eller har vært $\mathrm{i}$ villrede, som jeg var, men jeg anser at det senere vil være behov for fyldigere veiledning til medlemmene fra Legeforeningens juridiske avdeling. Det er fortsatt uklart for meg om ansvarsforsikringen er uten verdi for den forsikrede legen som ikke har autorisasjon etter fylte 75 år.

\section{Behov for veiledning}

I USA, der det er tradisjon for søksmål for det meste, medførte frykt for astronomiske erstatningsbeløp til at også helsepersonell vegret seg for å hjelpe ved ulykker og akutt sykdom utenfor arbeidssituasjonen. Dette førte til at det ble vedtatt lover som tok sikte på å frita hjelper fra denne risikoen, kalt «Good Samaritan Law» (2).

Jeg vet ikke om dette også er uttrykt i norsk lov, men antar at det må være en del av de generelle prinsipper for nødrett. Plikten til å hjelpe mennesker som er i akutt nød gjelder for alle, uansett yrke og kompetanse, men forutsetter at man vet hva man gjør. Aktsomhetskravene gjelder også for

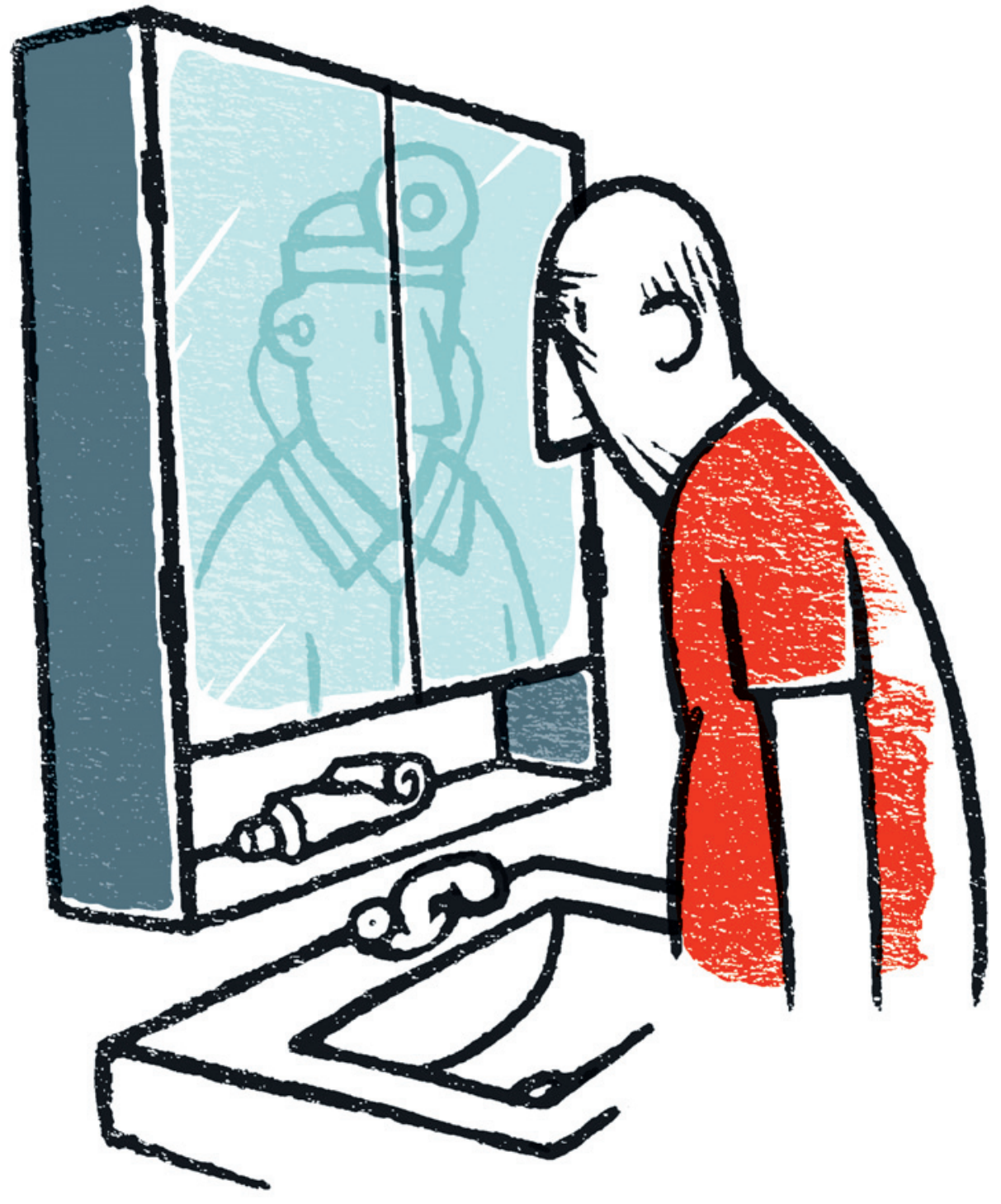

Illustrasjon @ Supernøtt popsløyd

alle, men alvorlige feilvurderinger med fatalt utfall må antas å utløse de alvorligste konsekvensene for helsepersonell.

Lov om helsepersonell gir anvisning om de omfattende plikter som en autorisert lege har. Etter opphør av autorisasjon gjenstår den personlige moralske plikten, som for den enkelte kan være like sterk. Man vil alltid gjøre sitt beste for å hjelpe, men hva forventes det av en lege uten autorisasjon? Denne gruppen bør i større grad enn det som gjelder i dag få Legeforeningens råd om rettstilstanden og, ikke minst, generelle råd om når man kan eller bør ha rett til å erklære seg ikke kompetent til å gå inn i en kritisk situasjon. Dette må ses i sammenheng med den raske utrykning av kompetent personell via AMK-sentral som er regelen i Norge.

Noen kan innvende at dette er hypotetiske problemstillinger som enhver får takle på egen hånd. Men for den som rammes, kan det bli en katastrofe. Jeg minner om artiklene som omhandlet hva man skulle 
eller burde gjøre på flyreiser når det oppstår akutt sykdom om bord (3-5). De mange som har avsluttet sin aktive legegjerning trenger rådgivning.

\section{Odd Johan Frisvold}

ojofrisv@online.no

Ålesund

Odd Johan Frisvold (f. 1934) er spesialist i indremedisin og i hjertesykdommer. Han er pensjonert avdelingsoverlege og tidligere sjeflege, tidligere medlem av landsstyret og sentralstyret og tidligere formann i Overordnede sykehuslegers forening.

Forfatter har fylt ut ICMJE-skjemaet og oppgir ingen interessekonflikter.

\section{Litteratur}

1. Frisvold OJ. Seniorpolitikk - inklusjon eller eksklusjon? Tidsskr Nor Lægeforen 2000; 120 : 3316-7

2. Wikipedia. Parable of the Good Samaritan. http://en.wikipedia.org/wiki/Good_Samaritan (13.2.2012)

3. Hafting M. Er det noen lege til stede? Tidsskr Nor Lægeforen 1997; 117: 2516.

4. Husom N. Når en passasjer blir pasient i luften. Tidsskr Nor Lægeforen 1998; 118: 3685

5. Söderfeldt B. Traumatologi för amatörer - läkaren som privatperson vid svåra olyckor. Läkartidningen 1998; 95: 310-1.

Mottatt 9.2. 2012 og godkjent 16.2. 2012. Medisinsk redaktør Siri Lunde. 